\title{
Arachidonate 5-Lipoxygenase
}

National Cancer Institute

\section{Source}

National Cancer Institute. Arachidonate 5-Lipoxygenase. NCI Thesaurus. Code C68729.

Arachidonate 5-lipoxyg enase protein $(674 \mathrm{aa}, \sim 78 \mathrm{kDa}$ ) is encoded by the human ALOX5 gene. This protein plays a role in the synthesis of leukotrienes from arachidonic acid; thus, it mediates both inflammation and allergen responses. 